Int. Agrophys., 2021, 35, 235-250

INTERNATIONAL

\title{
Drip loss control technology of frozen fruit and vegetables during thawing: a review**
}

\author{
Jianghong $W u^{1,2}$, Min Zhang ${ }^{1,3} \mathbb{D}^{*}$, Bhesh Bhandari ${ }^{4}$, and Chao-hui Yang ${ }^{5}$ \\ ${ }^{1}$ State Key Laboratory of Food Science and Technology, Jiangnan University, 214122 Wuxi, Jiangsu, China \\ ${ }^{2}$ Jiangsu Province Key Laboratory of Advanced Food Manufacturing Equipment and Technology, Jiangnan University, China \\ ${ }^{3}$ International Joint Laboratory on Food Safety, Jiangnan University, Jiangnan University, China \\ ${ }^{4}$ School of Agriculture and Food Sciences, University of Queensland, Brisbane, QLD, Australia \\ ${ }^{5}$ Yangzhou Yechun Food Production \& Distribution Co., Yangzhou 225200, Jiangsu, China \\ Received June 14, 2021; accepted September 15, 2021
}

\begin{abstract}
Frozen fruit and vegetables are types of natural foods without any additives, they are becoming more and more popular because of the seasonal supply of fresh fruit and vegetables, rich nutrition content, convenient consumption, sanitary condition, and favourable preservation performance which only requires simple technology. They are also a type of processed primary agricultural product with a good market share. However, the quality maintenance of frozen fruit and vegetables is a major problem with their preservation. Moreover, a significant number of researchers have been exploring many advanced technologies to maintain their qualities during the preservation process. In this article, the research status of drip loss control technology during the thawing of frozen fruit and vegetables is summarized in three respects: surface predehydration pretreatment, optimal freezing processes and thawing modes, and also its development trend is briefly explored.

Keyw ords: fruit and vegetables, drip loss, dehydration, freezing, thawing
\end{abstract}

\section{INTRODUCTION}

With the continuous improvement of living standards, people are paying more attention to the nutritional content and freshness of vegetables and fruit. It is quite

*Corresponding author e-mail: min@jiangnan.edu.cn

**The research was supported by a grant from Key R \& D projects of Xinjiang Uygur Autonomous Region of China (No. 2020B02017-1 (2021-2022)), the National Key R\&D Programme of China (Contract No. 2017YFD0400501 (20172021)), the 111 Project (BP0719028 (2017-2022)), the Jiangsu Province (China) "Collaborative Innovation Centre for Food Safety and Quality Control" Industry Development Programme, and the National First-Class Discipline Programme of Food Science and Technology (No. JUFSTR20180205 (2018-2021)). fitting therefore that the optimization of food processing technology has always been the research direction of agricultural product processing and the focus of the food industry (Yousuf et al., 2018). Only by continuously exploring new food preservation technologies can a dominant position in the market be attained while meeting the needs of consumers.

Fruit and vegetables can provide the human body with vitamins, antioxidants and dietary fibre, which are beneficial to many aspects of health. Also, fruit and vegetables could help to prevent non-communicable diseases (Turner et al., 2021). However, fruit and vegetables are perishable, and their storage period is very short. Therefore, the industry often post-processes fruit and vegetables to prolong their shelf lives and realize the seasonal supply and distribution area of fruit and vegetables (Liu et al., 2020). Tahir et al. (2019) discussed the application of chewing gum to serve as an edible coating for the preservation of food (Tahir et al., 2019). Panahirad studied the application of active edible coatings based on carbohydrate methyl cellulose and pectin in the food preservation field (Panahirad et al., 2021). In addition to film preservation technology, people also freeze foods to realize a longer shelf life. This method can inhibit the activity of microorganisms as well as enzymes in fruit and vegetables, thereby extending their shelf lives and greatly enhancing the maintenance of the original quality attributes of food (Chassagne-Berces et al.,

(C) 2021 Institute of Agrophysics, Polish Academy of Sciences 
2010). Therefore, fruit and vegetables can be frozen to maintain good food quality when they are transported, and then thawed before consumption (Suutarinen et al., 2000).

When the frozen food is thawed, the water produced by the melting of ice crystals can't be completely absorbed by the tissues and returns to its original state before freezing. Some of this water leaks from the inside of the food and becomes a lost fluid. This phenomenon is called drip loss. The drip loss value is usually expressed as a percentage of the initial weight of the product. Drip loss or the release of water during thawing involves the loss of nutrients in frozen foods, which is an important deterioration phenomenon commonly found in such foods (Kaale et al., 2014). Different varieties of fruit and vegetables have different cell structures (cell size, cell shape, pore size, and cell wall thickness) (Joardder et al., 2014; Zdunek et al., 2008). The cell structure of defrosted fruit and vegetables may be different than before freezing due to drip loss. During freezing, due to the formation of ice crystals, changes in the internal osmotic pressure of the tissues promote changes in the microstructure of plant cells, including the folding of the cell wall, the division of the middle layer, the expansion of the intercellular space and the contraction of the tissue, which in turn causes freezing damage (Li et al., 2018). Using an inappropriate freezing method will seriously damage the integrity of the cell tissue structure, leading to unnecessary physical and chemical changes, which in turn leads to irreversible quality loss and the structural destruction of fruit and vegetables (Van Buggenhout et al., 2006). Moreover, it can easily cause the thawing plant cell structure to collapse as well as decreasing the water storage capacity of the cell. In the actual freezing and thawing process of foods, due to improper processing or different operating techniques, the degree of drip loss from fruit and vegetables is different, which seriously affects their quality and application in subsequent processing. Drip loss is affected by many factors, such as the size of the defrosting food product as well as the distribution of ice crystals and the thawing rate (Van Buggenhout et al., 2006). Reducing drip loss is conducive to maintaining the original quality of the frozen food to the greatest extent possible, and ensuring that the food has a better appearance, flavour, aroma and texture after thawing (Cano et al., 1990). Therefore, it is particularly significant to control the drip loss of foods. Tu et al. (2015) pointed out that ultrasound freezing can increase the freezing rate and hardness, and reduce drip loss to an extent which is obvious (Tu et al., 2015). Tang et al. (2020b) found that the lowest drip loss for cherries under a permanent magnetic field and an alternating magnetic field were $4.79 \%$ and $4.64 \%$ (Tang et al., 2020b). Otero et al. (2000) found that high-pressure-translocation freezing can prevent cell mass loss due to icing or the presence of a large number of ice crystals (Otero et al., 2000). Liu et al. (2021) proposed that a combined treatment consisting of the application of a pulsed electric field and vacuum drying can significantly speed up the freezing and thawing process (Liu et al., 2021).
Redmond et al. (2004) found that freeze-chilling as well as freezing make no difference to the texture of cooked green beans $(p>0.05)$ but instead it resulted in a significantly higher drip loss than chilling $(\mathrm{p}<0.001)$ (Redmond et al., 2004).

For the most part this article discusses the three processes of surface pre-dehydration, freezing and thawing of frozen fruit and vegetables. The research progress achieved to date in the field of drip loss control technology during the thawing of frozen fruit and vegetables is introduced. It also anticipates the development of the frozen food industry. This approach provides a certain reference basis for the preservation and processing of fruit and vegetables.

\section{OSMOTIC DEHYDRATION}

Osmotic dehydration (OD) is usually used as a dehydration pretreatment method before fruit and vegetables are frozen. Because it mainly depends on cell membrane permeability as well as cell structure, OD is a slow countercurrent mass transfer process (Rizzolo et al., 2014). During the process of osmotic dehydration, it has been found that the plant cell wall shrinks and thickens, loses its original shape, and the cell gap as well as the free water in the cell gradually decreases. Excessive outer diffusion of moisture can cause the degradation of cell wall structure, increase the membrane rupture rate, reduce cell volume and cause the collapse of the plasmodesmata channel (Bialik et al., 2020; Fernandes et al., 2008; Wang et al., 2019). For the most part the osmotic dehydration generation system may be described by three elements: the osmotic solution, the cell membrane and cell tissue. The driving force for the OD process is the difference in the chemical potential of the semipermeable membrane between the cell material and the osmotic solution. Due to the existence of this pressure difference, the semi-permeability of the cell membrane of plant tissues as well as the fact that water molecules are relatively small, the water in the cells transfers to the hypertonic solution. The mass transfer process is shown in Figure 1. Water is mainly removed through diffusion and capillary flow, while the absorption of solutes only takes place through the diffusion process (Dash et al., 2019). Since the cell membrane of plant tissues is not completely selective, penetrants with a smaller molecular volume can easily penetrate into the cells. Intracellular solutes such as minerals, vitamins, sugars or organic acids may also flow into the high-pressure osmotic solution. This transfer is insignificant in quantity, but is crucial to product quality. Therefore, the compatibility between dissolved substances and food ingredients must be an important criterion (Dash et al., 2019).

The osmotic dehydration process has been applied to many foods, such as apples, apricots, bananas, carrots, oranges, grapes, guava, papaya, mango, potatoes, etc. (see Table 1 - specific applications). Osmotic dehydration can help to inhibit enzymatic browning. In addition, during this process, the cells can absorb the dissolving agent and extract the food 


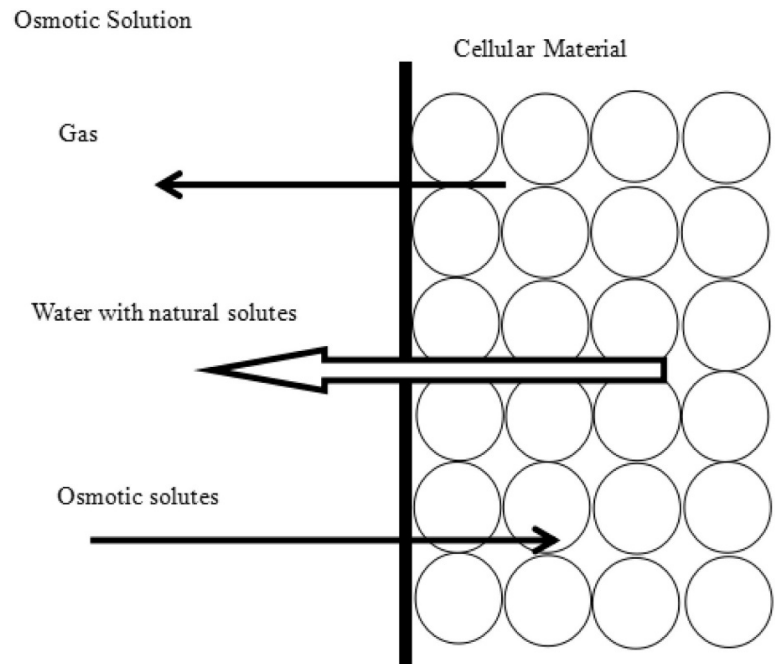

Fig. 1. The mass transfer process during the osmotic dehydration of fruit and vegetables (Qiu et al., 2019).

components, this results in changes to the original product components, thereby improving the nutrition, function and organic properties of fruit and vegetables (Kulczyński et al., 2021). If sugar or syrup is used as a penetrant, the flavour retention is also more pronounced (Chandra and Kumari, 2015). In addition, water loss results in an increase in solute concentration and a decrease in the water activity of the product. Moreover, most of its biological activities are inhibited, and the product is more stable during storage. Cvetković et al. (2019) studied the osmotic dehydration of cabbage in beet molasses and found that compared with fresh cabbage, the content of iron and potassium, sorbitol, catechin, p-cumene, caffeic acid and gallic acid in the beet molasses experimental group treated by osmotic dehydration increased with no increase in sodium content. Dermesonlouoglou et al. (2007) reported that high-DE maltodextrin and an oligofructose/ trehalose mixture in the osmotic solution provides the most ideal sensory characteristics after OD treatment. The frozen tomatoes that had undergone osmotic dehydration pretreatment had a harder texture after thawing compared to the untreated group. They also had a strong red colour and retained vitamin $\mathrm{C}$ to a greater extent during the freezing and storage process (Dermesonlouoglou et al., 2007).

Since the semi-permeable cell membranes in plant tissue are resistant to the mass transfer process, the mass transfer rate as well as the transfer speed during the dehydration process are limited. Therefore, enhancing the permeability of cell membranes to achieve rapid dehydration has become the development trend of OD. The mass transfer mechanism in the OD process is affected by various rate control parameters. Many researchers have found that the osmotic solute (composition and concentration), food traits (physical and chemical properties) as well as processing conditions (time, stirring or temperature) all affect the mass transfer rate (Cheng et al., 2014). Temperature is the primary parameter which is controlled by food industries in order to shorten the running time of the OD process. Increasing the temperature will improve the cell membrane permeability and accelerate mass transfer during the OD process. However, high temperatures will have a negative impact on food quality. Dehydrated products which are dried using the traditional hot air method always suffer from flavour loss, colour degradation, tissue damage as well as nutrient loss (Khin et al., 2005). In recent times, much research effort has been focused on developing a non-thermal pretreatment to change the permeability of cell membranes, such as ultrasound, a pulsed electric field, vacuum, high pressure and so on. A large number of cells are transformed and dehydrated quickly, thereby shortening the dehydration time and ameliorating the quality of their frozen state (Amami et al., 2005; Islam et al., 2014; Rastogi et al., 2007; Xin et al., 2014b).

Power ultrasound promotes the alternating compression and expansion of the material (the so-called "sponge effect"), which causes the natural cell structure of the material to rupture locally and form microchannels. These channels

Table 1. Some research concerning osmotic dehydration pretreatment prior to freezing

\begin{tabular}{|c|c|c|c|}
\hline Food & Condition & Conclusion & Reference \\
\hline Broccoli & $\begin{array}{l}\text { Samples are immersed in a concentrated } \\
\text { solution containing } 40 \% \text { trehalose and } \\
3 \% \text { sodium chloride, and the ratio of the } \\
\text { sample to water is set as } 1: 4 \text {. }\end{array}$ & $\begin{array}{l}\text { Compared with the samples without osmotic dehydra- } \\
\text { tion before freezing, the drip loss, colour, hardness and } \\
\text { L-ascorbic acid content of broccoli were significantly } \\
\text { improved. }\end{array}$ & Xin et al., 2014a \\
\hline Pineapple & $\begin{array}{l}\text { Osmotic dehydration is performed using } \\
\text { sucrose high-pressure solution } 60^{\circ} \mathrm{Brix} \\
\text { at } 40^{\circ} \mathrm{C} \text {, and osmotic dehydration detec- } \\
\text { tion is performed at } 45^{\circ} \mathrm{C} \text {. }\end{array}$ & $\begin{array}{l}\text { In the 1-hour osmotic dehydration pineapple sample, } \\
\text { the drip loss is greater than in the sample that has not } \\
\text { been exposed to the high-pressure solution. } \\
\text { Afterwards, the value of drip loss decreased with the } \\
\text { progress of the dehydration of vegetable tissues. }\end{array}$ & $\begin{array}{l}\text { Ramallo and } \\
\text { Mascheroni, } 2010\end{array}$ \\
\hline Tomato & $\begin{array}{l}\text { In } 55 \%(\mathrm{w} / \mathrm{w}) \text { maltodextrin solution, } \\
\text { osmotic dehydration was carried out at } \\
35^{\circ} \mathrm{C} \text { for } 24 \mathrm{~h}\end{array}$ & $\begin{array}{l}\text { Drip loss and nutritional quality loss after thawing was } \\
\text { significantly reduced. }\end{array}$ & Li et al., 2017 \\
\hline $\begin{array}{l}\text { Pears, kiwi- } \\
\text { fruit, } \\
\text { strawberries } \\
\text { and apples }\end{array}$ & $\begin{array}{l}\text { Osmotic dehydration with different sol- } \\
\text { utes (Sucrose, Glucose, Fructose, HMW } \\
\text { sugars) for different periods of time and } \\
\text { after freezing in a conventional air-blast } \\
\text { tunnel at }-40^{\circ} \mathrm{C}\end{array}$ & $\begin{array}{l}\text { Osmotic dehydration prior to freezing proved to limit } \\
\text { drip loss, reduce colour change and improve texture. }\end{array}$ & Marani et al., 2007 \\
\hline
\end{tabular}


have a low resistance to water diffusion therefore the rate of osmotic dehydration increases. Microscopic channels are formed by the elongation and flattening of cells in certain areas of the sample. During this process, no sign of the loss of cell wall strength and cell breakdown was observed. (Alvino Granados and Kawai, 2021; Duan et al., 2008; Fernandes et al., 2008; Xu et al., 2014a; Zhang et al., 2020a). There have been many studies which have reported the ultrasound osmotic dehydration OD process. Fan et al. (2020) found that the sponge effect of the micro-channels generated by ultrasound helps to increase the large-scale transformation of osmotically dehydrated kiwifruit, and the drip loss of the ultrasound-assisted osmotic dehydration group is $8 \%$, while the drip loss of the osmotic dehydration treatment group is $13 \%$. In addition, with regard to the texture of the ultrasound OD treatment group, the treatment helped to retain the hardness, reduce the sourness, and retain the other flavours of kiwifruit (Fan et al., 2020). Ultrasonic OD before freezing has a good influence on reducing its freezing time as well as drip loss, maintaining the anti-acid content and firmness, and also maintaining flavour. Kowalski et al. (2014) pointed out that both the efficiency and durability of cherry dehydration have been improved by the use of ultrasonic-assisted osmotic dehydration pretreatment, while maintaining the soft pulp as well as the aroma of the fruit, and greatly reducing the loss of anthocyanin content (Kowalski and Szadzińska, 2014).

High hydrostatic pressure (HHP) osmotic dehydration as a non-thermal processing technique increases the permeability of cells and increases the mass transfer rate by increasing the pressure to rapidly diffuse the water in the raw material and destroy the cell wall structure of the raw material (Zhang et al., 2020a). At the same time, this high-pressure technology can also kill bacteria effectively (Rastogi et al., 2007). Luo et al. (2019) found that HHP pretreatment can effectively improve mass transfer during the OD process of plum fruit (Luo et al., 2019). The pressure range of HHP osmotic dehydration pretreatment is generally in the scope of 100 $800 \mathrm{MPa}$ (Rastogi et al., 2000). In addition, because it may improve food quality and maintain the organic characteristics of processed foods, HHP treatment is becoming more and more common in food processing (Nunez-Mancilla et al., 2011). Zhang et al. (2020b) performed HHP pretreatment on strawberry slices and found that HHP can destroy the microstructure and tissue structure of strawberries, as well as leading to the disintegration of cell wall components, thereby improving the water fluidity and drying efficiency of strawberry slices to a significant extent. At the same time, it also caused the release of anthocyanins into the interstitial space and increased the content of anthocyanins, which enhanced the bright red colour of the strawberry slices pretreated with HHP. Since anthocyanins are water-soluble molecules, increased water mobility makes the distribution of anthocyanins in tissues more even (Zhang et al., 2020b).
Pulse vacuum osmotic dehydration (PVOD) is another technology commonly used to lower the water content as well as the water activity of biological products. It presents a hydrodynamic mechanism that can introduce an osmotic solution into the pores of food (Awad et al., 2012; Sahin and Ozturk, 2016). Therefore, the mobility of the material under vacuum conditions is higher than that under normal pressure. Applying a vacuum in the first few minutes of OD can increase the mass transfer rate. The decreasing pressure resulted in a swell of gas in the pores of fruit and vegetables, this is expelled through a hydrodynamic mechanism which is strengthened by the pressure difference, thereby adding to the available contact area for large-scale migration (de Jesus Junqueira et al., 2017; Sahin and Ozturk, 2016). Moreno et al. (2016) proposed that processing at $40^{\circ} \mathrm{C} \mathrm{PVOD} / \mathrm{OH}$ and subsequently under drying conditions of $60^{\circ} \mathrm{C}$, in a $65^{\circ}$ Brix sucrose solution at $13 \mathrm{~V} \mathrm{~cm}^{-1}$, is better for dehydrating blueberries, because it results in higher mass transfer, a lower loss of phenolic components as well as a shorter dehydration time (Moreno et al., 2016).

Pulsed electric field (PEF) treatment is designed to induce cell membranes to form stomata through high-voltage amplitude electric waves. These pores may be short-lived (recoverable) or permanent (irreversible cell destruction). The extent to which transient/permanent porosity occurs is a function of the treated matrix and the applied PEF protocol. Liu et al. (2021) showed that in general, an electric field strength of between 0.5 and $3 \mathrm{kV}$ with a frequency of $1-100 \mathrm{~Hz}$ and short pulses (pulse width $1+100 \mu \mathrm{s}$ ) can cause irreversible damage to plant tissues (Liu et al., 2021). The appearance of cell membrane pores facilitates the diffusion of water and solutes, thereby accelerating the mass flow and dehydration process. Dermesonlouogloua et al. (2018) explored the influences of pulsed electric field assisted OD on the quality as well as the shelf life of kiwifruit before freezing. They found that the pulsed electric field improves the mass transfer rate of OD as well as reducing the hardness of osmotically dehydrated fruit. The brightness of the PEF osmotic dehydration group increased, the yellow colour was also enhanced along with the pleasant flavour and taste. Pulsed electric field assisted OD can be used for preparing high-quality and durable frozen sections of kiwifruit (Dermesonlouogloua et al., 2018). In the research of Yu et al. (2017), fresh blueberries had $2 \mathrm{kV} \mathrm{cm}$ cm $^{-1} \mathrm{PEF}$ applied to them at first, and then osmotic dehydration was performed in $70 \%$ sucrose syrup. Compared with the blueberry samples without PEF pretreatment, the PEF pretreatment group shortened the osmotic dehydration time of blueberries from $120 \mathrm{~h}$ to $48 \mathrm{~h}$ to reach the target moisture content. PEF pretreatment improved the microbial quality of the dried fruit, but did not affect the nutritional quality of the blueberries. The antioxidant activity of the blueberries and the content of total phenolics, anthocyanins, main phenolic acids and flavonols were all reduced (Yu et al., 2017). 
Osmotic dehydration combined with microwave drying technology has been extensively studied (Zhang et al., 2006). Microwaves cause the volumetric heating of wet solids, which results in a water vapour pressure gradient between the surface and the interior of products, this accelerates the transfer of moisture (Roknul et al., 2014). Microwave energy can be used in combination with osmotic dehydration to provide more rapid and uniform heating, thereby shortening the dehydration time (Ekezie et al., 2017). Han et al. (2018) found that among all of the pretreatment techniques examined, the microwave treatment resulted in the highest

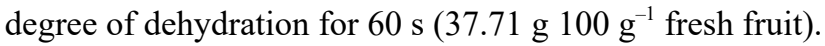
Compared with other pretreatment methods, microwave pretreatment has better dehydration performance in the osmotic dehydration process (Han et al., 2018). Sharif et al. (2018) declared that microwave pretreatment improved the dehydration of blueberries. Moreover, in the dehydrated samples, the retention rate of antioxidants such as phenol, flavonoids and anthocyanins obviously increased (Sharif et al., 2018). The influence of microwave dehydration on the texture, microstructure as well as on the moisture characteristics of apples was studied by Prothon et al. (2001). They concluded that the firmness of microwave dehydration pretreatment samples at $50^{\circ} \mathrm{C}$ was equal to that of the untreated ones and that the cell wall of the rehydrated samples did not rupture to a significant extent after microwave drying at $70^{\circ} \mathrm{C}$ (Prothon et al., 2001).

\section{Control of the freezing process}

Freezing is one of the most effective means for the longterm preservation of seasonal vegetables and fruit. Water is the most abundant component in fresh food cells, and most fruit and vegetables are more than $90 \%$ water. The main physical changes in fruit and vegetables during freezing and storage are water migration, ice crystal formation as well as recrystallization. Although it can inhibit the activity of microorganisms and enzymes, improper freezing will result in the formation of large ice crystals, irreversibly destroying the cell wall structure thereby producing a deterioration in food quality (Cong et al., 2019). Fresh vegetables and fruit with a high water content are more likely to form large ice crystals because of a decreased water retention capacity as well as the leakage of cell components during freezing, which results in some degree of cell structure destruction as well as to changes in texture and colour. The nutrition and quality of the frozen product also declines to a significant extent as a result. In addition, the recrystallization process during the period of frozen storage may also have a negative impact on the texture of the cell tissue, resulting in the nutrient loss and quality deterioration after thawing. To date, researchers have conducted extensive research to improve the ice crystal growth process and minimize the incidence of recrystallization (Liu et al., 2020).

\section{Control of the freezing rate}

The freezing rate which affects the nucleation and growth of ice crystals indirectly determines the shape, size as well as the distribution of ice crystals formed (Kiani and Sun, 2011). Figure 2 shows a typical freezing and water migration process, which visually shows the effect of freezing methods on plant cell structure. Freezing lowers the temperature of the external environment of the cell first, and gradually causes the formation of ice crystals outside the cell and releases latent heat, leading to an osmotic pressure difference between the interior and exterior of the cell. The water inside the cell slowly moves out of the cell, and water molecules gradually gather and form a growing structure on the foundation of a formation of extracellular ice crystals. Fast freezing is a process whereby the food is frozen to a low temperature $\left(-18^{\circ} \mathrm{C}\right.$ or lower) rapidly so that the frozen food may quickly pass through the largest

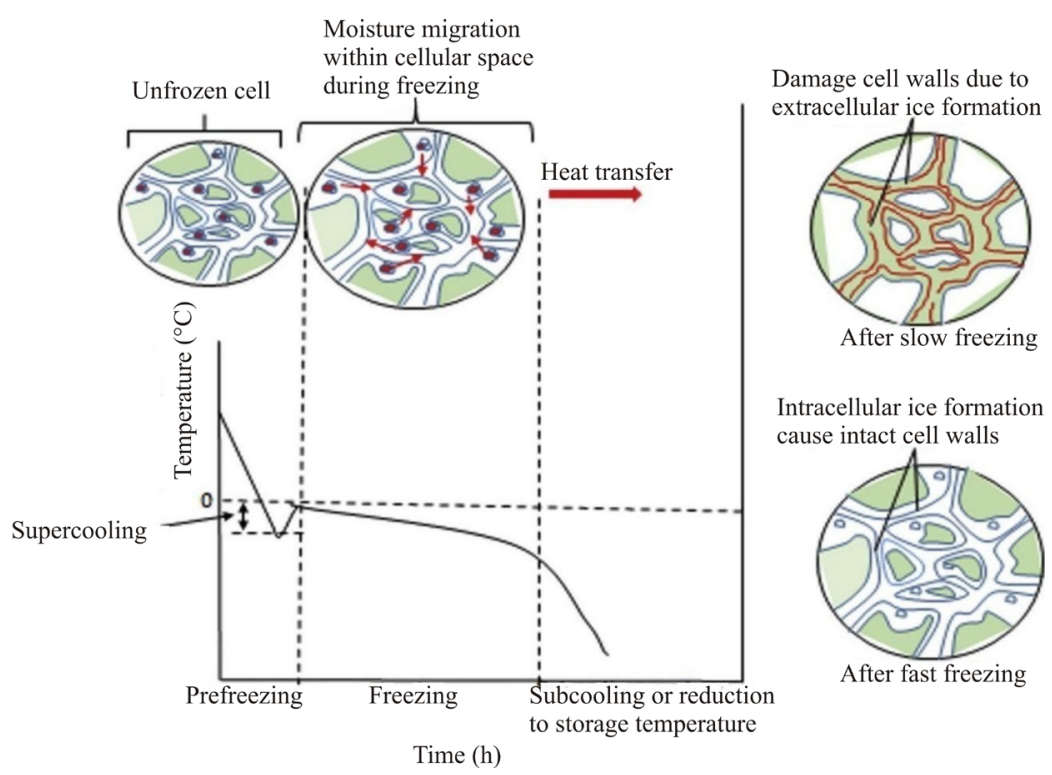

Fig. 2. Typical freezing and water migration process. 
ice crystal formation zone within $30 \mathrm{~min}$, and then form fine ice crystals. Slow freezing involves freezing food to a low temperature, slowly passing through the largest ice crystal formation zone to form larger ice crystals. After the cells are frozen, the cell membrane becomes deformed and damaged, the adhesion between the cells is weakened, the intercellular space is enlarged, the cell wall is deformed, consequently the cell wall of the cell membrane separates. Fast freezing usually includes the formation of intracellular ice crystals and produces a large amount of heat as well as mass transfer rates with minimal water migration, resulting in small uniform ice crystals which reduces freezing damage. It was found that the cells observed after rapid freezing were similar to those from fresh tissues. After thawing, the drip loss of fruit and vegetables will be reduced, so the original fresh flavour of the food can be maintained to a greater extent. On the other hand, slow freezing results in a decrease in cell uniformity and major changes in cell structure. Slow freezing allows the cells to form extracellular ice crystals, large ice crystals are easily formed which may pierce the cell membrane and cause the loss of cells due to mechanical damage ( $\mathrm{Li}$ et al., 2018). After thawing, drip loss is serious, the food has a deformed appearance, and nutrients as well as flavour molecules are lost. A study by Redmond et al. (2002) explored the effects of different freezing conditions on potato freezing, and found that rapid freezing can reduce drip loss as well as making the product softer, but at the same time VC is retained to a greater extent with little difference in taste compared to the fresh samples (Redmond et al., 2002). Rayman Ergün et al. (2021) reported that the higher freezing rate offers better prospects for the preservation of the tissue structure and cell wall, the antioxidant activity of the strawberries is retained to a greater extent after rapid freezing, and the brightness and redness of the fruit is better preserved during storage in the fast-frozen samples. (Rayman Ergün et al., 2021). Xu et al. (2014) discovered that drip loss from high-pressure carbon infusion (HPCI), liquid nitrogen and ultra-low temperature freezing (ULTF) as methods used to preserve frozen carrot slices were $8.29,12.36$ and $12.45 \%$, respectively. What is more, the samples frozen in $-80^{\circ} \mathrm{C}$ ULTF conditions showed the largest degree of pore and structural collapse, while HPCI freezing caused modest damage to the tissue due to the small ice crystals formed by rapid freezing. HPCI freezing leaves the sample with the highest $\alpha$ - and $\beta$-carotene content, the highest ascorbic acid retention rate, and just a minor decrease in hardness (Xu et al., 2014b).

The traditional freezing methods are cryogenic freezing, fluidized bed freezing and immersion freezing, and also combinations of these technologies. In recent times, new innovative freezing technologies have been rapidly developed, such as ultrasonic-assisted freezing, electric field freezing, high-pressure freezing, magnetic resonance freezing as well as microwave-assisted freezing. The new methods are mainly used to control the crystallization process to ameliorate the nucleation as well as the growth of ice crystals, increase the permeability of the cell wall, improve the freezing rate and mass transfer rate, reduce the freezing time, and retain the fresh quality of frozen vegetables and fruit (Wu et al., 2017). However, the specific freezing process parameters of these high-tech methods have not been unified so they cannot be commonly used as yet. Therefore, in the food processing industry, innovative technology research concerning the freezing process of food will continue to be a trend in the future growth of food freezing. The synergy of various innovative combinations with existing technologies in the freezing process requires a series

Table 2. Different auxiliary freezing technologies applied combining with freezing process

\begin{tabular}{|c|c|c|c|}
\hline Auxiliary technology & Principle & Effect & Reference \\
\hline $\begin{array}{l}\text { High pressure assisted } \\
\text { freezing }\end{array}$ & $\begin{array}{l}\text { Control and influence the phase transformation process. } \\
\text { External high pressure acts on the food material, increasing } \\
\text { the degree of supercooling and the number of nucleation, } \\
\text { instantly forming uniform ice core in the food material. }\end{array}$ & $\begin{array}{l}\text { The size of ice crystal was } \\
\text { small, and the quality of } \\
\text { frozen food was improved }\end{array}$ & $\begin{array}{l}\text { Cheng et al., } \\
2021\end{array}$ \\
\hline $\begin{array}{l}\text { Ultrasonic assisted } \\
\text { freezing }\end{array}$ & $\begin{array}{l}\text { Forming bubbles in liquid water, which has a perturbation } \\
\text { effect, helpful to heat transfer and improve the freezing rate. } \\
\text { The rupture of bubbles can stimulate nucleation, induce the } \\
\text { formation of ice crystals in cells or increase the nucleation } \\
\text { rate of ice crystals outside cells. }\end{array}$ & $\begin{array}{l}\text { The cavitation, thermal and } \\
\text { mechanical effects of ultra- } \\
\text { sound produced evenly } \\
\text { distributed smaller size ice } \\
\text { crystals }\end{array}$ & $\begin{array}{l}\text { Cheng et al., } \\
2014\end{array}$ \\
\hline $\begin{array}{l}\text { Electromagnetic wave } \\
\text { (RF, microwave) assisted } \\
\text { freezing }\end{array}$ & $\begin{array}{l}\text { Split large ice crystal, induce secondary crystallization; } \\
\text { Decreases the degree of supercooling; produces smaller ice } \\
\text { crystals. }\end{array}$ & Reduce ice crystal size & $\begin{array}{l}\text { Sadot et al., } \\
2017\end{array}$ \\
\hline $\begin{array}{l}\text { Electric field assisted } \\
\text { freezing (static / alternat- } \\
\text { ing electric field) }\end{array}$ & $\begin{array}{l}\text { Induce nucleation, reduce supercooling and increase phase } \\
\text { transformation time. }\end{array}$ & Small ice crystals & $\begin{array}{l}\text { Wang et al., } \\
2021 \mathrm{a}\end{array}$ \\
\hline $\begin{array}{l}\text { Magnetic field assisted } \\
\text { freezing }\end{array}$ & $\begin{array}{l}\text { Make the nuclear and electronic spins of water molecules } \\
\text { consistent with the direction of the magnetic field, to prevent } \\
\text { aggregation and maintain in supercooled conditions. }\end{array}$ & Inhibit ice crystal growth & $\begin{array}{l}\text { Tang et al., } \\
\text { 2020a }\end{array}$ \\
\hline
\end{tabular}


of in-depth investigations to be made (Ayala-Aponte and Cadena-G, 2014). Several common principles of innovative technology are shown in Table 2.

Ultrasonic waves generate cavitation bubbles in the transmission medium. The movement of cavitation bubbles will produce a microbeam effect, which can improve the efficiency of heat as well as mass transfer. At the same time, large ice crystals will be broken due to the microbeam effect, resulting in a further reduction in the size of the ice crystals, with the result that they become more uniform in size. In addition, cavitation bubbles can be used as a nucleating agent to increase the number of nucleation points and accelerate the nucleation process (Zhu et al., 2020). Therefore, ultrasonic-assisted freezing can increase freezing efficiency, improve the microscopic characteristics of frozen food, increase the heat as well as the mass transfer rate, and shorten the initiation time of crystallization (Tian et al., 2020). Moreover, Zhu et al. (2020) explored the impact of multi-frequency ultrasound-assisted freezing on potato quality. Compared with immersion freezing, ultrasonic treatment can reduce the drip loss during the thawing of potato samples to an obvious extent, its drip loss is lower at $5.24 \%$. Multi-frequency ultrasound can raise the freezing rate to an obvious extent, and the ice crystals formed are small in size and evenly distributed. The hardness, calcium content, L-antiquoric acid content as well as the whole phenol content of the potato are conserved well, and the drip loss after the thawing process is reduced. Multi-frequency ultrasound freezing can be used to better retain the quality of the frozen samples (Zhu et al., 2020). Xu et al. (2015) found that the carrot cell tissue showed better cell structure (less cell separation and interruption) under the intensification of ultrasonic power (UAF) of 0.17 to $0.26 \mathrm{~W} \mathrm{~cm}^{-1}$, and a better retainment of the hardness of the fresh samples. The application of ultrasound increased the freezing rate to an obvious extent, and UAF products significantly $(\mathrm{p}<0.05)$ decreased the drip loss for carrots as well as the loss of phytonutrients (anthocyanins, vitamin $\mathrm{C}$ and phenols). The effect on the volatile compounds of red radish was profound. In addition, freezing destroys the cell structure of Brassica vegetables, which leads to the degradation of glucosinolates and the formation of several decomposition products (Xu et al., 2015).

The magnetic field can interact with water and induce the water molecules to reorientate as well as readjust. These changes will restrain the molecules or stimulate the freezing of ice crystals. By making the nucleus and electron spin of the water molecule consistent with the direction of the magnetic field in order to prevent aggregation and keep it in a supercooled state, the freezing rate is accelerated and small ice crystals are formed without damaging the cell membrane (Maninder and Mahesh, 2020). Tang et al. (2020) found that the traditional freezing method severely damaged the structure of cherry cells with high drip loss $(10.39 \%)$. When the permanent magnetic field strength is $10 \mathrm{mT}$, the minimum drip loss is $4.79 \%$, and when the alternating magnetic field strength is $1.26 \mathrm{mT}$, the minimum drip loss is $4.64 \%$. The application of a magnetic field can reduce cell damage in the freezing process to a certain extent (Tang et al., 2020c). Maninder et al. (2020) pointed out that a magnetic field applied during the freezing process can cause food to have a higher degree of supercooling and also reduce the freezing time and temperature gradient, thereby reducing costs. With the application of a magnetic field, the ice crystals of food are fine and uniform, without poor mass transfer or cracks, and also the cell structure of the food is intact and the thawing loss is small. In addition, in terms of quality and appearance, the food retains flavour and freshness without acquiring a peculiar smell (Maninder and Mahesh, 2020). Kang's study found that the application of an oscillating magnetic field (OMF) during the freezing process inhibits the formation of ice cores. Mango slices treated with OMF50 are stored at $-5^{\circ} \mathrm{C}$ in an ultra-cold state, and can be stored for up to 7 days. Ultra-cold preservation may prolong the shelf life of fresh-cut mangoes and maintain their original quality (Kang et al., 2021).

Low-energy microwave-assisted freezing causes the formation of fine ice crystals, and can lead to the retention of better food quality attributes, this is conducive to the freezing of more sensitive cellular food substrates. Jha et al. (2020) applied constant microwave power $\left(167 \mathrm{~W} \mathrm{~kg}^{-1}\right)$ and pulsed MW power (500 and $667 \mathrm{~W} \mathrm{~kg}^{-1}$, with a $10 \mathrm{~s}$ pulse width as well as a 20 s pulse interval, with an average power of 167 and $222 \mathrm{~W} \mathrm{~kg}^{-1}$ ) to apples and potatoes. It was found that, compared to the control sample, under the conditions of constant radiation microwave freezing and under pulse radiation microwave freezing conditions, the drip loss value was reduced by about 3 and $42 \%$, respectively. The texture and colour of the apples and potatoes under different treatments did not change significantly (Jha et al., 2020).

\section{Control of storage temperature}

During frozen storage, temperature stability has an influence over the adjustment as well as the redistribution of ice crystals. A slight increase in temperature will cause the small ice crystals to thaw first, and, as the temperature drops again, the thawing ice crystals are redeposited on large ice crystals, forming larger ice crystals, which will further damage the cell structure. In order to prevent temperature fluctuations from causing secondary damage to cell structure and food quality, food is often stored in a glassy state (generally below $-18^{\circ} \mathrm{C}$ ) in the industry. EU Directive (89/108) recommends that during a storage period of 6 to 24 months, the storage temperature must remain steady and be kept below $-18^{\circ} \mathrm{C}$ (Gonçalves et al., 2011).

For glassy state foods, the molecular free volume is relatively small, the molecular flow resistance is high, the diffusion rate is low, and the molecular flow rate is significantly reduced (Alvino Granados and Kawai, 2021; Mahato et al., 2019). Therefore, with the lower migration speed of water molecules in the glassy state, it would be difficult for the melted water molecules to gather on the large ice 
crystals due to temperature fluctuations. Glass transition has an important influence on the texture of food, microbial activity, enzyme activity, and other chemical and physical changes (Noel et al., 1990). In the glassy state, all diffusion control reactions that cause changes in food quality become very slow, or even stop entirely (Cruz-Tirado et al., 2021). At this time, it may be considered that the storage of fruit and vegetables with a high water content in a long-term high-viscosity glassy state is the most stable arrangement, it is very beneficial for the storage of food and the maintenance of freshness and other desirable qualities. Atomized liquid nitrogen spray rapid freezing is used to achieve the glass transition temperature of food. It can be used to effectively maintain frozen food quality. This technology requires the sample storage temperature to be lower than the glass transition temperature ( $\mathrm{Tg})$. The lower the freezing temperature of the liquid nitrogen, the higher the freezing rate and the corresponding decrease in drip loss (Tian et al., 2020). Compared with freeze-concentration and rubber-like frozen storage, fruit and vegetables frozen below the glass transition temperature have a lower drip loss and are more stable under long-term freezing conditions (Zhang et al., 2017). In contrast, when the temperature is higher than $\mathrm{Tg}$ (glass state) and $\mathrm{Tm}$ (partially frozen concentrated state), the mobility of the water molecules in the system increases, and partially bound water becomes free water, thereby increasing the frozen water content, also the size of the ice crystals are also significantly increased, which easily damages the integrity of the cell tissues, leading to more drip loss. Zhang et al. (2017) found that frozen samples which are stored in a glassy state have better hardness (raised by 30.4-112.6\%), less drip loss (16.4-35.4\% reduction), better colour retention (31.6-54.0\% reduction in the total colour difference), and a higher level of ascorbic acid (9.8-60.3\% increase) (Zhang et al., 2017). Xu et al. (2020) explored the effect of temperature fluctuations on the state, ice crystal morphology, cell structure as well as the food quality of celery. The water storage value of drip loss in the glassy state is $6.8 \%$, and the drip loss value in the viscous flow state is $8.2 \%$ (Xu et al., 2020; Zhao et al., 2016). Zhang et al. (2017) studied the relationship between the vitamin $\mathrm{C}$ content in mangoes during cryopreservation and the water state as well as the extent ice crystal formation under different phase transitions (temperature fluctuations). The results showed that compared with other conditions (the rubber state and partially frozen concentrated state), the free water and frozen water content in the glassy frozen mango system is lower, the ice crystal size is smaller, and the degree of destruction to the mango tissue is also lower, therefore the vitamin C content is higher (Zhang et al., 2017).

\section{DEFROSTING METHOD}

Thawing is the last as well as the most important procedure to maximize the quality of frozen food, and the main goal of thawing is to reduce the thawing time in order to minimize the damage to food quality (Koizumi et al., 2006). The process melts the ice crystals inside the frozen food into water and restores the quality of the food to the same state as it was in before freezing. Thawing is usually a slower process than freezing. The size as well as the shape of the thawing material, thermal conductivity, initial and final temperature, thermal characteristics and temperature of the thawing medium, humidity (when thawing in the air), as well as the speed of the thawing medium will all have an effect on the thawing time (Zhu et al., 2004). Improper thawing conditions can cause drip loss, protein structure changes, microbial growth and texture changes, which may adversely affect many quality attributes of food, which in turn may profoundly affect the nutritional value and quality of the food. According to the classification of thawing rate, there are two thawing methods: slow thawing and rapid thawing. Slow thawing usually includes room temperature thawing, vacuum thawing as well as solution immersion thawing (Cai et al., 2019). Rapid thawing includes microwave thawing, ultrasonic thawing, ultra-high-pressure thawing, high voltage electrostatic thawing, medium electrolysis, electric heating thawing and other new rapid thawing methods. Rapid thawing will cause a serious loss of nutrients and a diminished taste, while thawing for too long will also most likely cause microbial contamination and serious drip loss (Cai et al., 2019). Therefore, the optimal thawing procedure should attract the attention of food technologists. Defrosting rapidly at low temperatures to prevent a significant temperature rise and excessive dehydration is an ideal way to retain the original food quality ( $\mathrm{Li}$ and Sun, 2002b).

The traditional defrosting methods use air as well as water for thawing. In the traditional process, thawing involves heat conduction inside the product, and heat is diverted from the surface to the centre through a hightemperature medium (such as air or water). After the food surface has been thawed, the frozen part is surrounded by a low thermal conductivity layer, which slows down the defrosting process, and this inevitably causes the quality of the food to decrease, such as the likelihood of it becoming contaminated with microorganisms, and excessive water loss caused by dripping or evaporation (Liu et al., 2019). To date, certain effective defrosting methods have been reported, such as far-infrared radiation thawing, high hydrostatic pressure thawing, ultra-high-pressure thawing, vacuum thawing, high-voltage pulsed electric field thawing, ultrasonic thawing as well as microwave thawing. Although many new defrosting methods have been discovered, there are as yet very few research programmes and applications concerning the control of the thawing mechanism and thawing parameters of fruit and vegetables, more research is being conducted into the thawing of meat products (LeBail et al., 2002). Table 3 describes the principles of common physics-assisted thawing technology. 
Table 3. Physical field assisted thawing technologies applied to frozen foods

\begin{tabular}{|c|c|c|c|c|}
\hline Unfreezing method & Principle & Advantage & Limitation & Reference \\
\hline $\begin{array}{l}\text { High voltage electro- } \\
\text { static thawing }\end{array}$ & $\begin{array}{l}\text { Electrostatic force promotes the acti- } \\
\text { vation of water molecules, thus } \\
\text { increasing the friction and collision } \\
\text { between water molecules, accelerating } \\
\text { the vibration, making ice in the form } \\
\text { of small ice crystals. }\end{array}$ & $\begin{array}{l}\text { No damage to tissue cells, } \\
\text { oxidation resistance, uni- } \\
\text { form and fast thawing, and } \\
\text { inhibition of bacterial pro- } \\
\text { liferation, reduced water } \\
\text { drip loss. }\end{array}$ & $\begin{array}{l}\text { High cost, protein dena- } \\
\text { turation, color change, } \\
\text { need a lot of equipment } \\
\text { space, safety. }\end{array}$ & $\begin{array}{l}\text { Jia et al., } \\
2017\end{array}$ \\
\hline Ultrasonic thawing & $\begin{array}{l}\text { Absorption of ultrasonic wave by the } \\
\text { frozen material and produce heat to } \\
\text { carry out the defrosting. }\end{array}$ & $\begin{array}{l}\text { Shorten the thawing time } \\
\text { and reduce the food } \\
\text { damage. }\end{array}$ & $\begin{array}{l}\text { Poor penetration, high } \\
\text { power requirements, } \\
\text { overheating caused by } \\
\text { local heating. }\end{array}$ & $\begin{array}{l}\text { Yuan et al., } \\
2020\end{array}$ \\
\hline $\begin{array}{l}\text { High voltage pulse } \\
\text { electric field thawing }\end{array}$ & $\begin{array}{l}\text { Electric field energy makes the micro- } \\
\text { scopic molecules, atoms and ions of } \\
\text { the matter in the field reach to the state } \\
\text { of high energy, thus accelerating the } \\
\text { collapse process of hydrogen bond. }\end{array}$ & $\begin{array}{l}\text { Fast thawing speed, uni- } \\
\text { form distribution of food } \\
\text { temperature after thawing, } \\
\text { less drip loss. }\end{array}$ & Expensive equipment. & $\begin{array}{l}\text { Wu et al., } \\
2017\end{array}$ \\
\hline RF thawing & $\begin{array}{l}\text { Frozen food move in alternating elec- } \\
\text { tric field, and the friction between } \\
\text { molecules generates heat, which accel- } \\
\text { erates the thawing process. }\end{array}$ & $\begin{array}{l}\text { Quick thawing speed, even } \\
\text { heating, less impact on the } \\
\text { quality of food. }\end{array}$ & $\begin{array}{l}\text { Poor heating uniform- } \\
\text { ity, easy to overheat at } \\
\text { the edge of food. }\end{array}$ & $\begin{array}{l}\text { Bedane } e t \\
\text { al., } 2018\end{array}$ \\
\hline $\begin{array}{l}\text { Microwave defrost- } \\
\text { ing/thawing }\end{array}$ & $\begin{array}{l}\text { Microwave can penetrate into the inte- } \\
\text { rior, so as to achieve the effect of } \\
\text { internal and external heating at the } \\
\text { same time, the internal ice crystal dis- } \\
\text { solves rapidly in the original position } \\
\text { of the organelle, which makes the } \\
\text { sample tissue quickly rehydrate. }\end{array}$ & $\begin{array}{l}\text { Shortens the defrosting } \\
\text { time, reduces the drip loss } \\
\text { rate, reduces the } \\
\text { microbial contamination. }\end{array}$ & $\begin{array}{l}\text { Heating uneven, and the } \\
\text { temperature difficult to } \\
\text { control. }\end{array}$ & $\begin{array}{l}\text { Llave et al., } \\
2020\end{array}$ \\
\hline
\end{tabular}

Microwaves are high-frequency electromagnetic waves which can rapidly penetrate fruit and vegetables. This causes polar molecules in fruit and vegetables to rub against each other to generate heat when they are thawed through the application of microwaves, so as to achieve the effect of internal and external heating. Microwave thawing is based on the dielectric properties of the material. The unique characteristics of microwave penetration and heat generation in food materials accelerates their thawing process and reduces cell damage and drip loss ( $\mathrm{Li}$ and Sun, 2002a). The thawing rate achieved for frozen samples through microwave thawing depends on the characteristics and dimensions of the sample as well as on the intensity and frequency of the electromagnetic radiation. Factors such as temperature changes, irregular shapes and food heterogeneity will affect the thawing process (Cai et al., 2020). However, the non-uniformity of the heating process limits the application of microwave thawing in food processing. Because of the great differences between the dielectric properties (DPs) of the solid and liquid phases of water in food, microwave heating leads to local overheating. In turn, this occurrence causes an excessive water shortage and also a thermochemical deterioration of the food (Llave et al., 2020). The microblog thawing heat treatment mechanism is shown in Fig. 3. Therefore, it is necessary to improve the heating uniformity during microwave thawing. Pupan et al. (2018) pointed out that after thawing in the refrigerator, the drip loss of samples stored at $-18^{\circ} \mathrm{C}$ for 3 months was $2.51 \%$, while the drip loss due to microwave thawing was $2.31 \%$. However, microwave thawing may introduce an unpleasant volatile compound to the food, resulting in poor overall aroma and flavour attributes (Pupan et al., 2018). Holzwarth et al. (2012) observed an increased drip loss for samples thawed at $37^{\circ} \mathrm{C}$ for $2 \mathrm{~h}$ and also for those thawed for $10 \mathrm{~min}$ in a microwave oven, these increases had values of 17.4 and $16.8 \%$, respectively. When strawberries are thawed in a microwave oven, the retention of anthocyanins is optimal, $10 \mathrm{~min}$ of thawing is beneficial for the maximum retention of ascorbic acid (Holzwarth et al., 2012).

Ultrasonic thawing relates to the attenuation of ultrasonic waves in food in order to generate the heat necessary to achieve the effect of thawing. Ultrasonic thawing cannot be widely used owing to the shortcomings of local heating, poor permeability and high-power requirements. Many factors affect the thawing process, such as ultrasonic frequency, ultrasonic intensity, sample orientation as well as the composition

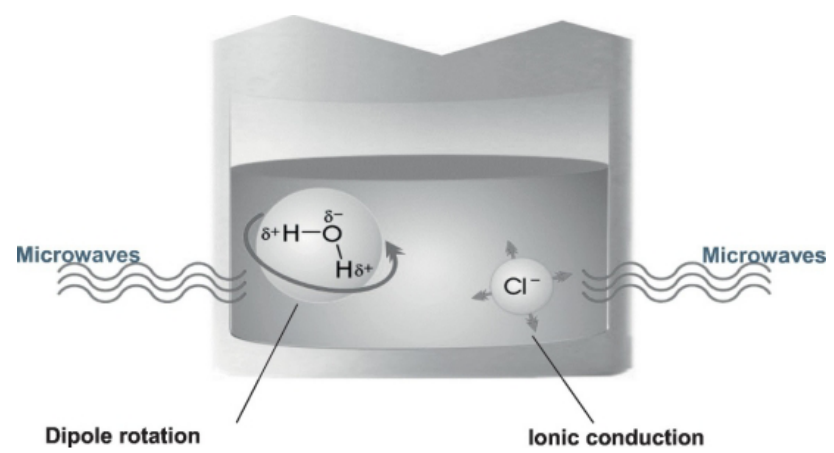

Fig. 3. The microwave thawing heat treatment mechanism (Khan et al., 2018). 


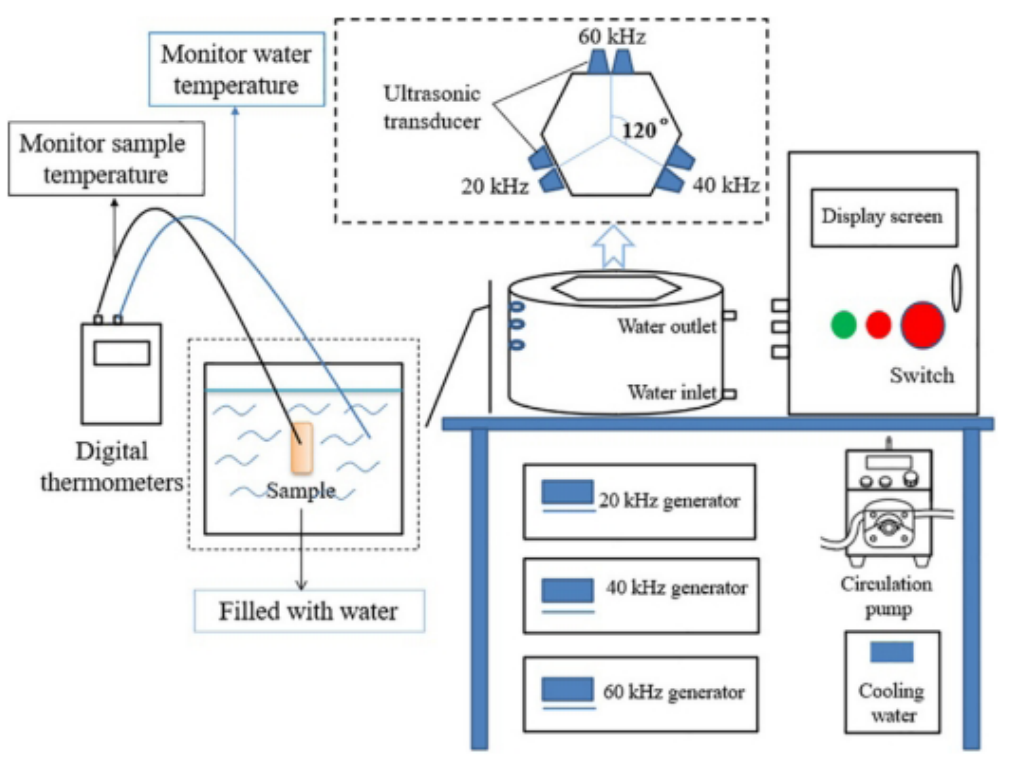

Fig. 4. Multi-frequency ultrasonic thawing equipment (Wang et al., 2021b).

of the thawed product. Ultrasonic frequency is a major factor during ultrasonic thawing (Qiu et al., 2020). Inappropriate ultrasonic conditions will destroy the quality of the food. Therefore, select a reasonable set of ultrasonic parameters for various frozen samples to speed up the thawing process, prevent surface overheating and ameliorate ultrasonic penetration induced by cavitation, they should also maintain the original quality of the thawed products to the greatest possible extent. Multi-frequency ultrasonic thawing equipment may be observed in Fig. 4. Liu et al. (2019) declared that the thawing time is shortened with the raising of ultrasonic intensity. In addition, the ultrasonic thawing treatment had almost no influence over the colour of the mango pulp. The texture as well as the aroma of the mango pulp thawed under low ultrasonic power is comparable to that of samples thawed in water. The higher the ultrasonic intensity, the greater the thawing efficiency as well as the increased quantity of phenolic acid released. However, when the ultrasonic intensity exceeds a certain range, the sensory quality of the mangoes deteriorates (Liu et al., 2019).

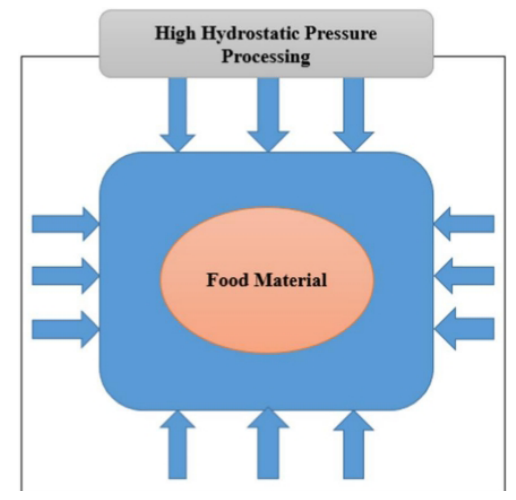

Fig. 5. Food system under high hydrostatic pressure (Khan et al., 2018).
Ultra-high pressure assisted thawing is achieved by applying high pressure to thaw frozen samples at a relatively low temperature. We may observe a food-processing system under high hydrostatic pressure in Fig. 5. When the pressure increases gradually, the phase transition temperature of the water gradually declines. At the same time, the temperature differences between the frozen materials and the thawed materials have increased to a significant extent. According to the Planck equation, the thawing time is inversely proportional to the temperature difference. Therefore, high-pressure thawing can significantly increase the thawing speed as well as reducing the thawing time. In addition, the specific heat capacity and enthalpy of the heated ice-containing solution are reduced, and the thermal conductivity of the ice under high pressure is increased, which helps to increase the rate of high-pressure thawing. Defrosting can improve food quality by adjusting the temperature, time, and pressure (Jia et al., 2020). To date, few researchers have reported the use of high pressure in the thawing process of frozen foods, and the research concerning high pressure auxiliary technology mainly involves the thawing of meat (Farag et al., 2009). Zhang et al. (2021) found that HHP treatment showed a greater likelihood in maintaining the colour of blueberry puree, and pressure treatment also played an auxiliary role in extracting anthocyanins. Under a pressure of $300 \mathrm{MPa}$, the content of blueberry anthocyanins was obviously increased. At the same time, such pressures can also improve PPO as well as $\beta$-glucosidase activity (Zhang et al., 2021). Ferrari et al. (2011) declared that appropriate temperature and high-pressure thawing can be used to maintain the natural quality of strawberry mousse as well as pomegranate juice, increase the extraction rate of polyphenols in the mousse, and have little influence on the content of polyphenols (Ferrari et al., 2011). 


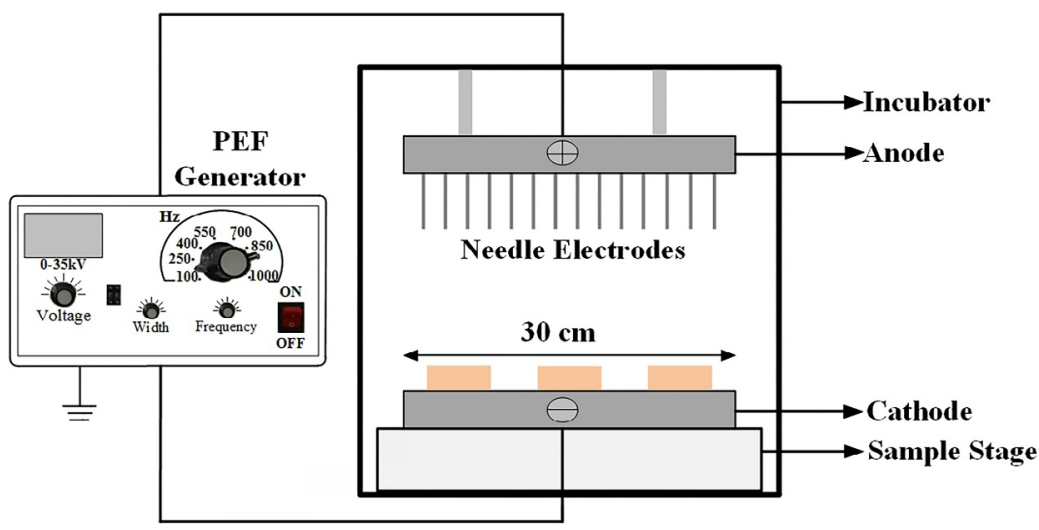

Fig. 6. Pulsed electric field thawing process (Li et al., 2020).

Pulsed electric field (PEF) is an emerging non-thermal technology that can be used to preserve better food quality as well as energy efficiency (Niu et al., 2020). The pulsed electric field thawing process may be observed in Fig. 6. When the frozen vegetables and fruit reach the intermediate stage, the corona discharge on the electrode surface ionizes the air, accelerates the momentum of the ions and transfers kinetic energy to the food ( $\mathrm{Li}$ et al., 2020). At the same time, the ions attached to the surface also increase the convective heat as well as mass transfer. A pulsed electric field can change the arrangement of native cells in plant tissues, leading to different electric waves of cells, which in turn promotes the thawing process. Wiktor et al. (2015) found that the texture of frozen and thawed products could be modified by PEF. PEF treatment greatly shortened the thawing time and changed the colour of the sample $(\Delta \mathrm{E}=5.74-19.58)$. Compared with untreated samples at $3 \mathrm{kV} \mathrm{cm}^{-1}$, the sample quality loss of 10 pulse treatments was lower $(1.6 \%)$. In addition, the sample became softer and less rigid with PEF pretreatment (Wiktor et al., 2015).

\section{CONCLUSION AND FUTURE PROSPECTS}

This article comprehensively describes various methods that can be used to control the drip loss in fruit and vegetables. For fresh fruit and vegetables, the cell microstructure is changed after dehydration and freezing, the cell membrane and cell wall are deformed and separated, the tissue is shrunk, thus controlling drip loss mainly serves the function of preventing damage to the cell wall structure and the integrity of the cell. With the general rise in living standards and the emphasis on the nutritional value of fruit and vegetables, as well as the ongoing in-depth research on food freezing and cold storage processing methods, drip loss after thawing has become one of the pivotal parameters influencing the quality of frozen foods. Controlling the freezing pretreatment (such as pre-dehydration), optimizing the freezing process, as well as the freezing storage temperature and thawing method can lessen the drip loss of frozen fruit and vegetables. In the process of freezing and thawing, various methods have been adopted. Among them are methods that are combined with physical auxiliary technology and can generally be applied to all stages of freezing and thawing of fruit and vegetables, they exert favourable influences concerning the maintenance of the original character of fruit and vegetables as well as keeping cell microstructure intact, decreasing drip loss as well as preserving fruit and vegetables. All of the techniques discussed will improve the organoleptic quality of fruit and vegetables. Cell hardness will maintain the hardness of the fresh fruit and vegetables to a greater extent, and their colour will be more intense. Compounds such as polyphenols, ascorbic acid and anthocyanins have the highest retention value. The flavour and taste of the processed fruit and vegetables may be different from those of fresh fruit and vegetables, but they are still acceptable and pleasant. The recent additions to thawing technology optimize the freezing and thawing process of food, and further improves the quality of food on the basis of traditional technology. However, the application of physically assisted freeze-thaw technology to control the drip loss of quick-frozen fruit and vegetables is still in the preliminary research stage and has as yet not been widely used in actual production. In terms of the control of drip loss, more research has been conducted to date on meat products as compared to the amount of research conducted on the cell structure of fruit and vegetables products which are more sensitive than meat products.

In terms of dehydration pretreatment and freezing technology, researchers are currently analysing the water in fruit and vegetable cells both theoretically and experimentally and linking processing parameters with crystal size, distribution and location as well as morphology to improve the freezing process and achieve the efficient freezing of fruit and vegetables. Of particular interest are new technologies such as ultrasound-assisted freezing, high-pressure freezing, magnetic resonance freezing and microwave-assisted freezing which have a positive effect on the nucleation or crystal growth steps of ice crystals, and are beneficial with regard to controlling crystallization. The combination or innovation of new technologies will be the development trend of dehydration and freezing food. The ultimate goal 
is to create large amounts of fine crystals to ensure better quality frozen food and biological materials. With regard to the thawing process, in recent years, researchers have rarely studied its mechanism in frozen fruit and vegetables. Therefore, research involving frozen fruit and vegetables will become a growing trend in the future, especially with regard to the development of effective thawing technology.

Conflict of interest: The authors do not declare any conflict of interest.

\section{ACKNOWLEDGMENTS}

We acknowledge all of which enabled us to carry out this study.

\section{REFERENCES}

Alvino Granados A.E., and Kawai K., 2021. Effect of cellulose powder content on the water sorption, glass transition, mechanical relaxation, and caking of freeze-dried carbohydrate blend and food powders. LWT-Food Sci. Technol., 148, 111798, https://doi.org/10.1016/j.lwt.2021.111798

Amami E., Vorobiev E., and Kechaou N., 2005. Effect of pulsed electric field on the osmotic dehydration and mass transfer kinetics of apple tissue. Dry. Technol., 23, 581-595, https:// doi.org/10.1081/DRT-200054144

Awad T.S., Moharram H.A., Shaltout O.E., Asker D., and Youssef M.M., 2012. Applications of ultrasound in analysis, processing and quality control of food: a review. Food Res. Int.,48,410-427,https://doi.org/10.1016/j.foodres.2012.05.004

Ayala-Aponte A. and Cadena-G M.I., 2014. The influence of osmotic pretreatments on melon (Cucumis melo L.) quality during frozen storage. Dyna, 81, 81-86, https://doi. org/10.15446/dyna.v81n186.38700

Bedane T.F., Altin O., Erol B., Marra F., and Erdogdu F., 2018. Thawing of frozen food products in a staggered throughfield electrode radio frequency system: A case study for frozen chicken breast meat with effects on drip loss and texture. Innov. Food Sci. Emerg. Technol., 50, 139-147, https:// doi.org/10.1016/j.ifset.2018.09.001

Bialik M., Wiktor A., Witrowa-Rajchert D., Samborska K., and Findura P., 2020. Osmotic dehydration and freezing pretreatment for vacuum drying kiwiberry: drying kinetics and microstructural changes. Int. Agrophys., 34, 265-272, https://doi.org/10.31545/intagr/118859

Cai L., Cao M., Regenstein J., and Cao A., 2019. Recent advances in food thawing technologies. Compr. Rev. Food Sci. Food Saf., 18, 953-970, https://doi.org/10.1111/1541-4337.12458

Cai L., Zhang W., Cao A., and Cao M., 2020. Effects of different thawing methods on the quality of largemouth bass (Micropterus salmonides). LWT-Food Sci. Technol., 120, 108908, https://doi.org/10.1016/j.lwt.2019.108908

Cano P., Marin M.A., and Fuster C., 1990. Freezing of banana slices. Influence of maturity level and thermal treatment prior to freezing. J. Food Sci., 55, 1070-1072, https://doi. org/10.1111/j.1365-2621.1990.tb01600.x

Chandra S. and Kumari D., 2015. Recent development in osmotic dehydration of fruit and vegetables: a review. Crit. Rev. Food Sci. Nutr., 55, 552-561, https://doi.org/10.1080/ 10408398.2012.664830
Chassagne-Berces S., Fonseca F., Citeau M., and Marin M., 2010. Freezing protocol effect on quality properties of fruit tissue according to the fruit, the variety and the stage of maturity. LWT-Food Sci. Technol., 43, 1441-1449, https:// doi.org/10.1016/j.lwt.2010.04.004

Cheng L., Zhu Z., and Sun D.-W., 2021. Impacts of high pressure assisted freezing on the denaturation of polyphenol oxidase. Food Chem., 335, 127485, https://doi. org/10.1016/j.foodchem.2020.127485

Cheng X.-F., Zhang M., and Adhikari B., 2014. Effects of ultrasound-assisted thawing on the quality of edamames (Glycine $\max (\mathrm{L}$.$) Merrill) frozen using different freezing$ methods. Food Sci. Biotech., 23, 1095-1102, https://doi. org/10.1007/s10068-014-0150-0

Cong C., Da-Zhang Y., and Jing X., 2019. Review on ice crystal shape and assisted freezing methods of quick-frozen food. Food and Machinery, 220-225.

Cruz-Tirado J.P., Martins J.P., Olmos B.D.F., Condotta R., and Kurozawa L.E., 2021. Impact of glass transition on chemical properties, caking and flowability of soymilk powder during storage. Powder Technol., 386, 20-29, https://doi.org/10.1016/j.powtec.2021.03.036

Cvetković B.R., Pezo L.L., Mišan A., Mastilović J., Kevrešan Ž., Ilić N., and Filipčev B., 2019. The effects of osmotic dehydration of white cabbage on polyphenols and mineral content. LWT-Food Sci. Technol., 110, 332-337, https://doi.org/10.1016/j.lwt.2019.05.001

Dash K.K., Balasubramaniam V.M., and Kamat S., 2019. High pressure assisted osmotic dehydrated ginger slices. J. Food Eng., 247, 19-29, https://doi.org/10.1016/j. jfoodeng.2018.11.024

de Jesus Junqueira J.R., Gomes Correa J.L., de Mendonca K.S., Resende N.S., and de Barros Vilas Boas E.V., 2017. Influence of sodium replacement and vacuum pulse on the osmotic dehydration of eggplant slices. Innov. Food Sci. Emerg. Technol., 41, 10-18, https://doi.org/10.1016/j. ifset.2017.01.006

Dermesonlouoglou E.K., Giannakourou M.C., and Taoukis P., 2007. Stability of dehydrofrozen tomatoes pretreated with alternative osmotic solutes. J. Food Eng., 78, 272-280, https://doi.org/10.1016/j.jfoodeng.2005.09.026

Dermesonlouggloua E., Zacharioua I., Andreoua V., and Taoukis P.S., 2018. Quality assessment and shelf-life modeling of pulsed electric field pretreated osmodehydrofrozen kiwifruit slices. Int. J. Food Stud., 7, 34-51, https://doi. org/10.7455/ijfs/7.1.2018.a4

Duan X., Zhang M., Li X., and Mujumdar A.S., 2008. Ultrasonically enhanced osmotic pretreatment of sea cucumber prior to microwave freeze drying. Dry. Technol., 26, 420426, https://doi.org/10.1080/07373930801929201

Ekezie F.-G.C., Sun D.-W., Han Z., and Cheng J.-H., 2017. Microwave-assisted food processing technologies for enhancing product quality and process efficiency: a review of recent developments. Trends Food Sci. Technol., 67, 58-69, https://doi.org/10.1016/j.tifs.2017.05.014

Fan K., Zhang M., Wang W., and Bhandari B., 2020. A novel method of osmotic-dehydrofreezing with ultrasound enhancement to improve water status and physicochemical properties of kiwifruit. Int. J. Refrig., 113, 49-57, https:// doi.org/10.1016/j.jirefrig.2020.02.013 
Farag K.W., Duggan E., Morgan D.J., Cronin D.A., and Lyng J.G., 2009. A comparison of conventional and radio frequency defrosting of lean beef meats: Effects on water binding characteristics. Meat Sci., 83, 278-284, https://doi. org/10.1016/j.meatsci.2009.05.010

Ferrari G., Maresca P., and Ciccarone R., 2011. The effects of high hydrostatic pressure on the polyphenols and anthocyanins in red fruit products. Proc. Food Sci., 1, 847-853, https://doi.org/10.1016/j.profoo.2011.09.128

Gonçalves E.M., Abreu M., Brandão T.R.S., and Silva C.L.M., 2011. Degradation kinetics of colour, vitamin $C$ and drip loss in frozen broccoli (Brassica oleracea L. ssp. Italica) during storage at isothermal and non-isothermal conditions. Int. J. Refrig., 34, 2136-2144, https://doi.org/10.1016/j. ijrefrig.2011.06.006

Han L., Xiaorui W., Yong Z., Hao X., Fei W., Chenghai L., Chai L., and Xianzhe Z., 2018. Research of microwave assisted osmotic dehydration process for blackcurrant whole fruit. Food Sci. Technol., 43, 104-112.

Holzwarth M., Korhummel S., Carle R., and Kammerer D.R., 2012. Evaluation of the effects of different freezing and thawing methods on color, polyphenol and ascorbic acid retention in strawberries (Fragaria $\times$ ananassa Duch.). Food Res. Int., 48, 241-248, https://doi.org/10.1016/j. foodres.2012.04.004

James C., Purnell G., and James S.J., 2014. A Critical Review of Dehydrofreezing of Fruits and Vegetables. Food Bioproc. Tech., 7, 1219-1234, https://doi.org/10.1007/ s11947-014-1293-y

Jha P.K., Chevallier S., Xanthakis E., Jury V., and Le-Bail A., 2020. Effect of innovative microwave assisted freezing (MAF) on the quality attributes of apples and potatoes. Food Chem., 309, https://doi.org/10.1016/j. foodchem.2019.125594

Jia F., Jing Y., Dai R., Li X., and Xu B., 2020. High-pressure thawing of pork: Water holding capacity, protein denaturation and ultrastructure. Food Biosci., 38, 100688, https://doi. org/10.1016/j.fbio.2020.100688

Jia G., Liu H., Nirasawa S., and Liu H., 2017. Effects of highvoltage electrostatic field treatment on the thawing rate and post-thawing quality of frozen rabbit meat. Innov. Food Sci. Emer. Technol., 41, 348-356, https://doi.org/10.1016/j. ifset.2017.04.011

Joardder M., Karim A., Kumar C., and Brown R.J., 2014. Effect of cell wall properties of plant tissue on porosity and shrinkage of dried apple. Int. J. Food Prop., 18, 2327-2337, https://doi.org/10.1080/10942912.2014.980945

Kaale L.D., Eikevik T.M., Rustad T., and Nordtvedt T.S., 2014. Changes in water holding capacity and drip loss of Atlantic salmon (Salmo salar) muscle during superchilled storage. LWT-Food Sci. Technol., 55, 528-535, https://doi. org/10.1016/j.lwt.2013.10.021

Kang T., You Y., Hoptowit R., Wall M.M., and Jun S., 2021. Effect of an oscillating magnetic field on the inhibition of ice nucleation and its application for supercooling preservation of fresh-cut mango slices. J. Food Eng., 300, 110541, https://doi.org/10.1016/j.jfoodeng.2021.110541

Khan M.K., Ahmad K., Hassan S., Imran M., Ahmad N., and Xu C., 2018. Effect of novel technologies on polyphenols during food processing. Innov. Food Sci. Emerg. Technol., 45, 361-381, https://doi.org/10.1016/j.ifset.2017.12.006
Khin M.M., Zhou W., and Perera C., 2005. Development in the Combined Treatment of Coating and Osmotic Dehydration of Food - a review. Int. J. Food Eng., 1(1), https://doi. org/10.2202/1556-3758.1005

Kiani H. and Sun D.-W., 2011. Water crystallization and its importance to freezing of foods: a review. Trends Food Sci. Technol., 22, 407-426, https://doi.org/10.1016/j.tifs.2011.04.011

Koizumi M., Naito S., Haishi T., Utsuzawa S., Ishida N., and Kano H., 2006. Thawing of frozen vegetables observed by a small dedicated MRI for food research. Magn. Reson. Imaging, 24, 1111-1119, https://doi.org/10.1016/j.mri.2006.07.004

Kong C.H.Z., Hamid N., Ma Q., Lu J., Wang B.-G., and Sarojini V., 2017. Antifreeze peptide pretreatment minimizes freeze-thaw damage to cherries: An in-depth investigation. LWT-Food Sci. Technol., 84, 441-448, https://doi.org/10.1016/j. lwt.2017.06.002

Kowalski S.J. and Szadzińska J., 2014. Convective-intermittent drying of cherries preceded by ultrasonic assisted osmotic dehydration. Chem. Engin. Process.-Process Intensification, 82, 65-70, https://doi.org/10.1016/j.cep.2014.05.006

Kulczyński B., Suliburska J., Rybarczyk M., and GramzaMichałowska A., 2021. The effect of osmotic dehydration conditions on the calcium content in plant matrice. Food Chem., 343, 128519, https://doi.org/10.1016/j.foodchem.2020.128519

LeBail A., Chevalier D., Mussa D.M., and Ghoul M., 2002. High pressure freezing and thawing of foods: a review. Int. J. Refrig., 25, 504-513, https://doi.org/10.1016/S0140-7007(01)00030-5

Li B. and Sun D.-W., 2002. Novel methods for rapid freezing and thawing of foods - a review. J. Food Eng., 54, 175-182, https://doi.org/10.1016/S0260-8774(01)00209-6

Li D., Zhu Z., and Sun D.-W., 2018. Effects of freezing on cell structure of fresh cellular food materials: a review. Trends Food Sci. Technol., 75, 46-55, https://doi.org/10.1016/j. tifs.2018.02.019

Li J., Chotiko A., Kyereh E., Zhang J., Liu C., Ortega V.V.R., Bankston D., and Sathivel S., 2017. Development of a combined osmotic dehydration and cryogenic freezing process for minimizing quality changes during freezing with application to fruits and vegetables. J. Food Process. Preserv., 41, 8, https://doi.org/10.1111/jfpp.12926

Li J., Shi J., Huang X., Zou X., Li Z., Zhang D., Zhang W., and Xu Y., 2020. Effects of pulsed electric field on freeze-thaw quality of Atlantic salmon. Innov. Food Sci. Emerg. Technol., 65, 102454, https://doi.org/10.1016/j.ifset.2020.102454

Liu C., Grimi N., Bals O., Lebovka N., and Vorobiev E., 2021. Effects of pulsed electric fields and preliminary vacuum drying on freezing assisted processes in potato tissue. Food Bioprod. Process., 125, 126-133, https://doi.org/10.1016/j. fbp.2020.11.002

Liu D.-K., Xu C.-C., Guo C.-X., and Zhang X.-X., 2020. Subzero temperature preservation of fruits and vegetables: a review. J. Food Eng., 275, 109881, https://doi. org/10.1016/j.jfoodeng.2019.109881

Liu Y., Chen S., Pu Y., Muhammad A.I., Hang M., Liu D., and Ye T., 2019. Ultrasound-assisted thawing of mango pulp: Effect on thawing rate, sensory, and nutritional properties. Food Chem., 286, 576-583, https://doi.org/10.1016/j. foodchem.2019.02.059 
Llave Y., Kambayashi D., Fukuoka M., and Sakai N., 2020. Power absorption analysis of two-component materials during microwave thawing and heating: Experimental and computer simulation. Innov. Food Sci. Emer. Technol., 66, 102479, https://doi.org/10.1016/j.ifset.2020.102479

Luo W., Tappi S., Wang C., Yu Y., Zhu S., Dalla Rosa M., and Rocculi P., 2019. Effect of high hydrostatic pressure (HHP) on the antioxidant and volatile properties of candied wumei fruit (Prunus mume) during osmotic dehydration. Food Bioproc. Tech., 12, 98-109, https://doi.org/10.1007/ s11947-018-2196-0

Mahato S., Zhu Z., and Sun D.-W., 2019. Glass transitions as affected by food compositions and by conventional and novel freezing technologies: a review. Trends Food Sci. Technol., 94, 1-11, https://doi.org/10.1016/j.tifs.2019.09.010

Maninder K. and Mahesh K., 2020. An innovation in magnetic field assisted freezing of perishable fruits and vegetables: a review. Food Rev. Int., 36, 761-780, https://doi.org/10.10 80/87559129.2019.1683746

Marani C.M., Agnelli M.E., and Mascheroni R.H., 2007. Osmo-frozen fruits: mass transfer and quality evaluation. J. Food Eng., 79, 1122-1130, https://doi.org/10.1016/j. jfoodeng.2006.03.022

Moreno J., Gonzales M., Zuniga P., Petzold G., Mella K., and Munoz O., 2016. Ohmic heating and pulsed vacuum effect on dehydration processes and polyphenol component retention of osmodehydrated blueberries (cv. Tifblue). Innov. Food Sci. Emerg. Technol., 36, 112-119, https://doi.org/10.1016/j. ifset.2016.06.005

Niu D., Zeng X.-A., Ren E.-F., Xu F.-Y., Li J., Wang M.-S., and Wang R., 2020. Review of the application of pulsed electric fields (PEF) technology for food processing in China. Food Res. Int., 137, 109715, https://doi.org/10.1016/j. foodres.2020.109715

Noel T.R., Ring S.G., and Whittam M.A., 1990. Glass transitions in low-moisture foods. Trends Food Sci. Technol., 1, 62-67, https://doi.org/10.1016/0924-2244(90)90048-4

Nunez-Mancilla Y., Perez-Won M., Vega-Galvez A., Arias V., Tabilo-Munizaga G., Briones-Labarca V., Lemus-Mondaca R., and Di Scala K., 2011. Modeling mass transfer during osmotic dehydration of strawberries under high hydrostatic pressure conditions. Innov. Food Sci. Emer. Technol., 12, 338-343, https://doi.org/10.1016/j.ifset.2011.03.005

Otero L., Martino M., Zaritzky N., Solas M., and Sanz P.D., 2000. Preservation of microstructure in peach and mango during high-pressure-shift freezing. J. Food Sci., 65, 466470, https://doi.org/10.1111/j.1365-2621.2000.tb16029.x

Panahirad S., Dadpour M., Peighambardoust S.H., Soltanzadeh M., Gullón B., Alirezalu K., and Lorenzo J.M., 2021. Applications of carboxymethyl cellulose- and pectin-based active edible coatings in preservation of fruits and vegetables: a review. Trends Food Sci. Technol., 110, 663-673, https://doi.org/10.1016/j.tifs.2021.02.025

Prothon F., Ahrne L.M., Funebo T., Kidman S., Langton M., and Sjoholm I., 2001. Effects of combined osmotic and microwave dehydration of apple on texture, microstructure and rehydration characteristics. LWT-Food Sci. Technol., 34, 95-101, https://doi.org/10.1006/fst1.2000.0745
Provesi J.G., Valentim Neto P.A., Arisi A.C.M., and Amante E.R., 2019. Extraction of antifreeze proteins from cold acclimated leaves of Drimys angustifolia and their application to star fruit (Averrhoa carambola) freezing. Food Chem., 289, 65-73, https://doi.org/10.1016/j.foodchem.2019.03.055

Pupan N., Dhamvithee P., Jangchud A., and Boonbumrung S., 2018. Influences of different freezing and thawing methods on the physico-chemical, flavor, and sensory properties of durian puree (cv. Monthong). J. Food Proces. Preserv., 42: e13669, https://doi.org/10.1111/jfpp.13669

Qiu L., Zhang M., Chitrakar B., and Bhandari B., 2020. Application of power ultrasound in freezing and thawing processes: Effect on process efficiency and product quality. Ultrason. Sonochem., 68, 105230, https://doi.org/10.1016/j. ultsonch.2020.105230

Qiu L., Zhang M., Tang J., Adhikari B., and Cao P., 2019. Innovative technologies for producing and preserving intermediate moisture foods: a review. Food Res. Int., 116, 90-102, https://doi.org/10.1016/j.foodres.2018.12.055

Ramallo L.A. and Mascheroni R.H., 2010. Dehydrofreezing of pineapple. J. Food Eng., 99, 269-275, https://doi. org/10.1016/j.jfoodeng.2010.02.026

Rastogi N.K., Angersbach A., and Knorr D., 2000. Synergistic effect of high hydrostatic pressure pretreatment and osmotic stress on mass transfer during osmotic dehydration. J. Food Eng., 45, 25-31, https://doi.org/10.1016/ S0260-8774(00)00037-6

Rastogi N.K., Raghavarao K.S.M.S., Balasubramaniam V.M., Niranjan K., and Knorr D., 2007. Opportunities and challenges in high pressure processing of foods. Crit. Rev. Food Sci. Nutr., 47, 69-112, https://doi.org/10.1080/10408390600626420

Rayman Ergün A., Yanat M., and Baysal T., 2021. The effects of the novel home freezing system on microstructure, color, antioxidant activity, and microbiological properties of strawberries. Int. J. Refrig., 121, 228-234, https://doi. org/10.1016/j.ijrefrig.2020.10.013

Redmond G.A., Butler F., and Gormley T.R., 2002. The effect of freezing conditions on the quality of freeze-chilled reconstituted mashed potato. LWT-Food Sci. Technol., 35, 201-204, https://doi.org/10.1006/fstl.2001.0838

Redmond G.A., Gormley T.R., and Butler F., 2004. The effect of short- and long-term freeze-chilling on the quality of cooked green beans and carrots. Innov. Food Sci. Emerg.Technol., 5, 65-72, https://doi.org/10.1016/j.ifset.2003.11.002

Rizzolo A., Vanoli M., Cortellino G., Spinelli L., Contini D., Herremans E., Bongaers E., Nemeth A., Leitner M., Verboven P., Nicolaï B.M., and Torricelli A., 2014. Characterizing the tissue of apple air-dried and osmo-air-dried rings by X-CT and OCT and relationship with ring crispness and fruit maturity at harvest measured by TRS. Innov. Food Sci. Emerg. Technol., 24, 121-130, https://doi. org/10.1016/j.ifset.2013.09.001

Roknul A.S.M., Zhang M., Mujumdar A.S., and Wang Y., 2014. A comparative study of four drying methods on drying time and quality characteristics of stem lettuce slices (Lactuca sativa L.). Dry. Technol., 32, 657-666, https://doi. org/10.1080/07373937.2013.850435

Sadot M., Curet S., Rouaud O., Le-Bail A., and Havet M., 2017. Numerical modelling of an innovative microwave assisted freezing process. Int. J. Refrig., 80, 66-76, https:// doi.org/10.1016/j.ijrefrig.2017.04.017 
Sahin U. and Ozturk H.K., 2016. Effects of pulsed vacuum osmotic dehydration (PVOD) on drying kinetics of figs (Ficus carica L). Innov. Food Sci. Emerg. Technol. 36, 104111, https://doi.org/10.1016/j.ifset.2016.06.003

Schudel S., Prawiranto K., and Defraeye T., 2021. Comparison of freezing and convective dehydrofreezing of vegetables for reducing cell damage. J. Food Eng., 293, 110376, https://doi.org/10.1016/j.jfoodeng.2020.110376

Sharif I., Adewale P., Dalli S.S., and Rakshit S., 2018. Microwave pretreatment and optimization of osmotic dehydration of wild blueberries using response surface methodology. Food Chem., 269, 300-310, https://doi.org/10.1016/j. foodchem.2018.06.087

Song D.H., Kim M., Jin E.-S., Sim D.-W., Won H.-S., Kim E.K., Jang S., Choi Y.S., Chung K.-H., and An J.H., 2019. Cryoprotective effect of an antifreeze protein purified from Tenebrio molitor larvae on vegetables. Food Hydrocoll., 94, 585-591, https://doi.org/10.1016/j.foodhyd.2019.04.007

Suutarinen J., Heiska K., Moss P., and Autio K., 2000. The Effects of Calcium Chloride and Sucrose Prefreezing Treatments on the Structure of Strawberry Tissues. LWT-Food Sci. Technol., 33, 89-102, https://doi.org/10.1006/ fstl.1999.0616

Tahir H.E., Xiaobo Z., Mahunu G.K., Arslan M., Abdalhai M., and Zhihua L., 2019. Recent developments in gum edible coating applications for fruits and vegetables preservation: a review. Carbohydr. Polym., 224, 115141, https://doi. org/10.1016/j.carbpol.2019.115141

Tang J., Shao S., Tian C., and 2020a. Effects of the magnetic field on the freezing process of blueberry. Int. J. Refrig., 113, 288-295, https://doi.org/10.1016/j.ijrefrig.2019.12.022

Tang J., Zhang H., Tian C., and Shao S., 2020b. Effects of different magnetic fields on the freezing parameters of cherry. J. Food Eng., 278, 109949, https://doi.org/10.1016/j. jfoodeng.2020.109949

Tian Y., Chen Z., Zhu Z., and Sun D.-W., 2020. Effects of tissue pre-degassing followed by ultrasound-assisted freezing on freezing efficiency and quality attributes of radishes. Ultrason. Sonochem., 67, 105162, https://doi.org/10.1016/j. ultsonch.2020.105162

Tu J., Zhang M., Xu B., and Liu H., 2015. Effect of physicochemical properties on freezing suitability of Lotus (Nelumbo nucifera) root. Int. J. Refrig., 50, 1-9, https://doi. org/10.1016/j.ijrefrig.2014.10.006

Turner G., Green R., Alae-Carew C., and Dangour A.D., 2021. The association of dimensions of fruit and vegetable access in the retail food environment with consumption; a systematic review. Glob. Food Sec., 29, 100528, https://doi. org/10.1016/j.gfs.2021.100528

Van Buggenhout S., Messagie I., Maes V., Duvetter T., Van Loey A., and Hendrickx M., 2006. Minimizing texture loss of frozen strawberries: effect of infusion with pectinmethylesterase and calcium combined with different freezing conditions and effect of subsequent storage/thawing conditions. Eur. Food Res. Technol., 223, 395-404, https://doi.org/10.1007/s00217-005-0218-4

Wang H., Liu C., Xue Y., and Li D., 2020. Correlation of mechanical properties of peach slices with cell wall polysaccharides and cell morphology during hot air predrying. J. Food Process. Preserv., 44: e14319, https://doi.org/10.1111/ jfpp.14319
Wang Q., Wang L., Tian Y., Zhu Z., and Sun D.-W., 2021a. Effects of ultrahigh permittivity ceramic on water freezing by high voltage electric field-assisted freezing system. Int. J. Refrig., 128, 271-280, https://doi.org/10.1016/j.ijrefrig.2021.02.022

Wang Y.-Y., Yan J.-K., Rashid M.T., Ding Y., Chikari F., Huang S., and Ma H., 2021b. Dual-frequency sequential ultrasound thawing for improving the quality of quick-frozen small yellow croaker and its possible mechanisms. Innov. Food Sci. Emerg. Technol., 68, 102614, https://doi. org/10.1016/j.ifset.2021.102614

Wiktor A., Schulz M., Voigt E., Witrowa-Rajchert D., and Knorr D., 2015. The effect of pulsed electric field treatment on immersion freezing, thawing and selected properties of apple tissue. J. Food Eng., 146, 8-16, https:// doi.org/10.1016/j.jfoodeng.2014.08.013

Wu X.-F., Zhang M., Adhikari B., and Sun J., 2017. Recent developments in novel freezing and thawing technologies applied to foods. Crit. Rev. Food Sci. Nutr., 57, 3620-3631, https://doi.org/10.1080/10408398.2015.1132670

Xin Y., Zhang M., and Adhikari B., 2014a. The effects of ultrasound-assisted freezing on the freezing time and quality of broccoli (Brassica oleracea L. var. botrytis L.) during immersion freezing. Int. J. Refrig., 41, 82-91, https://doi. org/10.1016/j.ijrefrig.2013.12.016

Xin Y., Zhang M., and Adhikari B., 2014b. Freezing Characteristics and Storage Stability of Broccoli (Brassica oleracea L. var. botrytis L.) under Osmodehydrofreezing and Ultrasound-assisted Osmodehydrofreezing Treatments. Food Bioproc. Technol., 7, 1736-1744, https://doi.org/10.1007/ s11947-013-1231-4

Xu B.-G., Zhang M., Bhandari B., Cheng X.-F., and Islam M.N., 2015. Effect of ultrasound-assisted freezing on the physico-chemical properties and volatile compounds of red radish. Ultrason. Sonochem., 27, 316-324, https://doi. org/10.1016/j.ultsonch.2015.04.014

Xu B., Chen J., Yuan J., Azam S.M.R., and Zhang M., 2021. Effect of different thawing methods on the efficiency and quality attributes of frozen red radish. J. Sci. Food Agric., 101, 3237-3245, https://doi.org/10.1002/jsfa.10953

Xu B., Zhang M., Bhandari B., and Cheng X., 2014a. Influence of ultrasound-assisted osmotic dehydration and freezing on the water state, cell structure, and quality of radish (Raphanus sativus L.) cylinders. Dry. Technol., 32, 1803-1811, https:// doi.org/10.1080/07373937.2014.947427

Xu C.-C., Liu D.-K., Zhang L., Chen X.-J., Sui Y.-C., Zhang H.-Z., and Ma H., 2020. Influence of temperature fluctuations on the state/phase, ice crystal morphology, cell structure, and quality of celery during frozen storage. LWTFood Sci. Technol., 125, 109219, https://doi.org/10.1016/j. lwt.2020.109219

Xu Z., Guo Y., Ding S., An K., and Wang Z., 2014b. Freezing by immersion in liquid $\mathrm{CO}_{2}$ at variable pressure: Response surface analysis of the application to carrot slices freezing. Innov. Food Sci. Emerg. Technol., 22, 167-174, https://doi. org/10.1016/j.ifset.2013.06.005

Yousuf B., Qadri O.S., and Srivastava A.K., 2018. Recent developments in shelf-life extension of fresh-cut fruits and vegetables by application of different edible coatings: a review. LWT-Food Sci. Technol., 89, 198-209, https://doi. org/10.1016/j.lwt.2017.10.051 
Yu Y., Jin T.Z., Fan X., and Xu Y., 2017. Osmotic dehydration of blueberries pretreated with pulsed electric fields: Effects on dehydration kinetics, and microbiological and nutritional qualities. Dry. Technol., 35, 1543-1551, https://doi.org/1 0.1080/07373937.2016.1260583

Yuan J., Li H., Tao W., Han Q., Dong H., Zhang J., Jing Y., Wang Y., Xiong Q., and Xu T., 2020. An effective method for extracting anthocyanins from blueberry based on freezeultrasonic thawing technology. Ultrason. Sonochem., 68, 105192, https://doi.org/10.1016/j.ultsonch.2020.105192

Zdunek A., Gancarz M., Cybulska J., Ranachowski Z., and Zgorska K.J.I.A., 2008. Turgor and temperature effect on fracture properties of potato tuber (Solanum tuberosum cv. Irga). Int. Agrophys., 22, 89-97.

Zhang L., Liao L., Qiao Y., Wang C., Shi D., An K., and Hu J., 2020a. Effects of ultrahigh pressure and ultrasound pretreatments on properties of strawberry chips prepared by vacuum-freeze drying. Food Chem., 303, https://doi. org/10.1016/j.foodchem.2019.125386

Zhang L., Qiao Y., Wang C., Liao L., Shi D., An K., Hu J., Wang J., and Shi L., 2020b. Influence of high hydrostatic pressure pretreatment on properties of vacuum-freeze dried strawberry slices. Food Chem., 331, https://doi. org/10.1016/j.foodchem.2020.127203

Zhang M., Tang J., Mujumdar A.S., and Wang S., 2006. Trends in microwave-related drying of fruits and vegetables. Trends Food Sci. Technol., 17, 524-534, https://doi. org/10.1016/j.tifs.2006.04.011
Zhang W., Shen Y., Li Z., Xie X., Gong E.S., Tian J., Si X., Wang Y., Gao N., Shu C., Meng X., Li B., and Liu R.H., 2021. Effects of high hydrostatic pressure and thermal processing on anthocyanin content, polyphenol oxidase and $\beta$-glucosidase activities, color, and antioxidant activities of blueberry (Vaccinium Spp.) puree. Food Chem., 342, 128564, https://doi.org/10.1016/j.foodchem.2020.128564

Zhang Y., Zhao J.-H., Ding Y., Nie Y., Xiao H.-W., Zhu Z., and Tang X.-M., 2017. Effects of state/phase transitions on the quality attributes of mango (Mangifera indica L.) during frozen storage. Int. J. Food Sci. Technol., 52, 239-246, https://doi.org/10.1111/ijfs.13275

Zhao J.H., Liu F., Pang X.L., Xiao H.W., Wen X., and Ni Y.Y., 2016. Effects of different osmo-dehydrofreezing treatments on the volatile compounds, phenolic compounds and physicochemical properties in mango (Mangifera indica L.). Int. J. Food Sci. Technol., 51, 1441-1448, https://doi. org/10.1111/ijfs.13113

Zhu S., Ramaswamy H.S., and Simpson B.K., 2004. Effect of high-pressure versus conventional thawing on color, drip loss and texture of Atlantic salmon frozen by different methods. LWT-Food Sci. Technol., 37, 291-299, https://doi. org/10.1016/j.lwt.2003.09.004

Zhu Z., Zhang P., and Sun D.-W., 2020. Effects of multi-frequency ultrasound on freezing rates and quality attributes of potatoes. Ultrason. Sonochem., 60, 104733, https://doi. org/10.1016/j.ultsonch.2019.104733 